\title{
Author Correction: Đakrông virus, a novel mobatvirus (Hantaviridae) harbored by the Stoliczka's Asian trident bat (Aselliscus stoliczkanus) in Vietnam
}

\author{
Satoru Arai $\oplus^{1}$, Keita Aoki, Nguyễn Trường Sơn, Vương Tân Tú, Fuka Kikuchi, Gohta Kinoshita, \\ Dai Fukui, Hoàng Trung Thành, Se Hun Gu, Yasuhiro Yoshikawa, Keiko Tanaka-Taya, \\ Shigeru Morikawa, Richard Yanagihara \& Kazunori Oishi
}

Correction to: Scientific Reports https://doi.org/10.1038/s41598-019-46697-5, published online 15 July 2019

The Acknowledgements section in this Article is incomplete.

"We thank Hitoshi Suzuki, Shinichiro Kawada, Satoshi D. Ohdachi and Kimiyuki Tsuchiya for supporting field investigations and for valuable advice. This work was supported in part by a grant-in-aid Research on Emerging and Re-emerging Infectious Diseases, Health Labour Sciences Research Grant in Japan (H25-Shinko-Ippan-008), grants-in-aid on Research Program on Emerging and Re-emerging Infectious Diseases, Japan Agency for Medical Research and Development (AMED) JP15fk0108005, JP16fk0108117, JP17fk0108217, JP18fk0108017 and JP19fk0108097, grant-in aid from the Japan Society for the Promotion of Science 24405045 (Scientific Research grant B), grant-in-aid on NAFOSTED (106-NN.05-2016.14), and VAST-JSPS (QTJP01.02/18-20)."

should read:

"We thank Hitoshi Suzuki, Shinichiro Kawada, Satoshi D. Ohdachi and Kimiyuki Tsuchiya for supporting field investigations and for valuable advice. This work was supported in part by a grant-in-aid Research on Emerging and Re-emerging Infectious Diseases, Health Labour Sciences Research Grant in Japan (H25-Shinko-Ippan-008), grants-in-aid on Research Program on Emerging and Re-emerging Infectious Diseases, Japan Agency for Medical Research and Development (AMED) JP15fk0108005, JP16fk0108117, JP17fk0108217, JP18fk0108017 and JP19fk0108097, grant-in aid from the Japan Society for the Promotion of Science 24405045 (Scientific Research grant B), grant-in-aid on NAFOSTED (106-NN.05-2016.14), and VAST-JSPS (QTJP01.02/18-20). Support was also provided by U.S. Public Health Service grant P30GM114737 from the National Institutes of Health."

Additionally, this Article contains errors in Reference 38 which was incorrectly given as:

Sikes, R. S. \& Animal, C. \& Use Committee of the American Society of, M. 2016 Guidelines of the American Society of Mammalogists for the use of wild mammals in research and education. J Mammal 97, 663-688, https:// doi.org/10.1093/jmammal/gyw078 (2016).

The correct reference is listed below:

Sikes, R. S. \& Animal Care \& Use Committee of the American Society of Mammalogists. 2016 Guidelines of the American Society of Mammalogists for the use of wild mammals in research and education. J Mammal 97, 663-688, https://doi.org/10.1093/jmammal/gyw078 (2016). 
(c) (i) Open Access This article is licensed under a Creative Commons Attribution 4.0 International License, which permits use, sharing, adaptation, distribution and reproduction in any medium or format, as long as you give appropriate credit to the original author(s) and the source, provide a link to the Creative Commons license, and indicate if changes were made. The images or other third party material in this article are included in the article's Creative Commons license, unless indicated otherwise in a credit line to the material. If material is not included in the article's Creative Commons license and your intended use is not permitted by statutory regulation or exceeds the permitted use, you will need to obtain permission directly from the copyright holder. To view a copy of this license, visit http://creativecommons.org/licenses/by/4.0/.

(C) The Author(s) 2020 